\title{
Human ochratoxicosis and nephropathy in Egypt: A preliminary study
}

\author{
E W Wafa, R S Yahya, M A Sobh, I Eraky, M El-Baz, H A M El-Gayar, A M Betbeder \\ and E E Creppy
}

Urology and Nephrology Center, Mansoura University, Egypt

\begin{abstract}
This preliminary study was designed to delineate the extent of the problem of ochratoxicosis and its relation to renal diseases mounting to end stage renal disease (ESRD) or urothelial tumors in Egypt. It comprised 71 patient with renal diseases of different presentations. They were divided into five groups: (group 1 - no. $=11$ ) patients with $(E S R D)$ under conservative treatment, (group $2-$ no. $=15$ ) ESRD on regular hemodialysis, (group3 - no. $=15$ ) renal allograft recipients, (group $4-$ no. $=15$ ) patients with nephrotic syndrome and (group $5-$ no. $=15$ ) patients with urothelial tumors. In addition, two control groups were included; potential related donors for renal transplantation (group $6-$ no. $=15$ ) and healthy controls with negative family history of renal disease (group 7 - no. $=25$ ).

All groups were subjected to clinical, laboratory, radiological and histopathological evaluation of renal status together with determination of ochratoxin A level in blood, urine and in biopsy specimens of patients with urothelial tumors.

High ochratoxin blood levels were found in all patients with ESRD (groups $1 \& 2)(p<0.01)$. Higher blood levels were detected in the group on conservative treatment (group 1) in comparison to controls possibly due to ochratoxin A clearance by dialysis. Ochratoxin A was detected in blood and urine of renal transplant recipients (group3) $(p<0.01)$ and especially higher levels were found in patients with nephrotic syndrome (group 4) $(p<0.001)$.
\end{abstract}

Correspondence and offprint requests to: Ehab W Wafa, Consultant of Nephrology, Urology \& Nephrology Center, Mansoura, Egypt.
Patients with urothelial tumor (group 5), had higher levels of ochratoxin in blood, urine and tissue biopsy specimens $(p<0.01)$.

These results support the conclusion that ochratoxinA could be related to the genesis of renal disease leading to ESRD or causing urothelial cancer. We recommend more detailed study for ochratoxicosis \& renal disease in Egypt.

\section{Introduction}

Mycotoxicosis are increasingly implicated in human and animal diseases both in industrial and developing countries. In the latter, malnutrition may be an aggravating factor for its mycotoxinogenic effect [I]. Ochratoxin A (OTA) has been identified in a number of animal food (mainly cereals, dried foods, coffee and cocoa) and also in the blood of animals and human after consumption of contaminated food in the Balkans, Germany, France, Canada and Scandinavian Countries [2-11]. The molecular mode of action and metabolism had been studied by several laboratories [12]. In the last decade, several authors presented data in favor of OTA nephroloxicity in human $[4,13,14]$. Epidemiological data on OTA levels in food [15], showed higher figures in some countries especially Tunisia, Canada, Australia, Bulgaria, Germany and Egypt. In these countries more than $50 \%$ of samples were contaminated [15] thus the risk of OTA induced human renal disease has to be considered. There is high incidence of ESRD of unknown etiology in most of these countries which 
could be correlated to mycotoxins - especially OTA contaminated food $[12,16,18]$.

Certain data merit considering the role of OTA in inducing chronic renal failure. Balkan Endemic Nephropathy (BEN) is probably the best studied although the data are not totally convincing, however, the fact that immigrants from non-endemic regions are liable to be affected $15-20$ years after moving into endemic areas support the idea of an enviromental toxin [3]. Recently, OTA was supposed to be incriminated in causing of acute renal failure due to acute tubular necrosis (ATN) in one case in Italy [19] and several cases of chronic interstitial nephritis in Tunisia [17].

In addition to this nephrotoxic effect, OTA is also known for its hepatotoxic, teratogenic, immunosuppressive and carcinogenic properties. Several reports demonstrated suppression of the $\operatorname{IgM} \& \operatorname{IgG}$ antibodies formation in mice. Further more recent literature pointed to the carcinogenic potentials of OTA, both in mouse and rat [6] as well as in human [20]. The latter authors reported striking high incidence of urinary tract tumors (UTT) in BEN particularly neoplasms of the renal pelvis and ureter and correlated it to OTA.

The role of OTA intoxication in the genesis of renal diseases or urothelial tumor will be evaluated in this preliminary study. Analysis of blood, urine and tissues of patients with different renal disorders for their OTA contents will be done.

\section{Materials and methods}

\section{Patients}

Patients enrolled in this study were inpatients in Urology \& Nephrology Center Mansoura, Egypt, with proven renal lesions or urothelial tumor.

A total of 71 patients were included and classified into five groups. (group l) patients with ESRD under medical treatment $(n=11)$, (group 2) patients with ESRD under dialytic therapy $(n=15)$, (group 3 ) renal allograft recipients $(n=15)$, (group 4) patients with nephrotic syndrome $(n=15)$ and (group 5) patients with urothclial cancer $(n=15)$.

Two control groups were included:

1. Healthy donors for renal transplantation $(n=15)$. They were selected for donation after thorough clinical, radiological and laboratory investigation (group 6).

2. Healthy personnel, working in the Urology and Nephrology Center, Mansoura, Egypt, with negative family history of renal disease $(n=25)$ (group 7). They were also subjected to thorough clinical, laboratory and radiological evaluation to exclude those with any renal troubles. The selected controls have a low level of urinary B2 microglobulin. The results of B2 microglobulin were obtained by ELISA on freshly collected urine samples, using Eurogenetics diagnostic kit (coated microtiter strips).

The total number of samples was 231 (106 urine samples, 111 blood samples and 14 tissue biopsy specimens from patients with urothelial cancer).

All cases were subjected to full medical history including dietary habits as well as clinical, biological, histopathological and radiological investigations.

Biological check up included: S. creatinine, uric acid, plasma proteins, blood picture and urine analysis. Radiological evaluation of the kidney status was done by plain radiology and ultrasound. Ochratoxin A level in blood, urine and tissue samples were determined.

\section{Biological samples}

For each patient, $10 \mathrm{ml}$ samples of urine and blood were collected and stored at $4^{\circ} \mathrm{C}$ until analysis. From patients with urothelial tumors, $3 \mathrm{gm}$ tissue samples were taken by cystoscopy and stored at $80^{\circ} \mathrm{C}$.

The extraction procedure was carried out in the Urology and Nephrology Center, Mansoura, Egypt; and the analysis by HPLC in "Laboratoire de Toxicologie et d'Hygiéne Appliqudée, Université Bordeaux 2, France".

\section{Determination of $\dot{O} T A$}

\section{Extraction procedure:}

- Urine and serum: To $3 \mathrm{ml}$ of urine or serum, 40 $\mathrm{ml}$ of $0.2 \mathrm{M}$ magnesium chloride and $0.1 \mathrm{M} \mathrm{Hcl}$ $(20: 20, v / v)$ were added and then adjusted to $\mathrm{pH}$ 2.5 by $1 \mathrm{~N} \mathrm{Hcl}$. The OTA was extracted with chloroform $(10 \mathrm{ml})$ and the organic phase was washed by $0.1 \mathrm{M}$ sodium bicarbonate $(2 \times 10 \mathrm{ml})$. The aqueous alkaline phase was adjusted to $\mathrm{pH}$ 2.5 by $1 \mathrm{~N} \mathrm{Hcl}$ and extracted by chloroform $(10 \mathrm{ml})$. The chloroform layer was evaporated to dryness, the residue was dissolved in $1.8 \mathrm{ml}$ methanol and kept for HPLC analysis.

- Tissue: $3 \mathrm{~g}$ tissue sample was extracted by crushing in $4.5 \mathrm{ml} 0.2 \mathrm{M}$ magnesium chloride and $0.1 \mathrm{M} \mathrm{Hcl}(1: 1 \mathrm{v} / \mathrm{v})$, then washed by $2.25 \mathrm{ml}$ of the same extraction mixture. The obtained extract was centrifuged for 5 minutes at $4000 \mathrm{rpm}$ and the aqueous middle layer was defatted by shaking with $3 \mathrm{ml} \mathrm{n}$-hexane and centrifuged again. $3 \mathrm{ml}$ of the defatied extract was subjected to the same extraction procedure mentioned under urine and serum . 
2. Analytical methods:

The OTA concentration was determined in serum and urine extracts, by HPLC and microfluorometric detection.

- Equipment: A Bischoff pump Model A 2200, an Alcott autosampler Model 738, a Lichrosorb C18,10 um precolumn, a Spherisorb ODS 10um column $(250 \times 4.0 \mathrm{~mm})$ and Jasco 821 -FP fluorescence HPLC monitor.

- Liquid chromatography conditions: Mobile phase methanol, acetonitrile, sodium acetate $5 \mathrm{mM}$, acetic acid (300:300:400:14 v/v/v/v), injection volume $50 \mu \mathrm{l}$; flow rate: $1.5 \mathrm{ml} / \mathrm{min}$; fluorescent detection: excitation at $340 \mathrm{~nm}$ and emission at $465 \mathrm{~nm}$. Analytical data were collected, stored and treated using the software Pic 3 developed by ICS (instrumentation Consumable Service, France). The quantification of OTA was achieved automatically by the computer according to the peak surface of three OTA standards $(5,10$ and $2 \mathrm{O}$ $\mathrm{ng} / \mathrm{ml}$ ) injected sequentially with ochratoxin-free methanol.

- Hydrolysis of OTA for confirmation: $1 \mathrm{ml}$ of the methanolic extract was evaporated to dryness, dissolve in $0.9 \mathrm{ml}$ of $0.04 \mathrm{M}$ Tris in $1 \mathrm{M} \mathrm{NaCl}$ and adjusted to $\mathrm{pH} 7.5$ by $\mathrm{Hcl} 100 \mu \mathrm{l}$ of carboxypeptidase A (Sigma, Ref.C0261, 100U/ml) were added and incubated for 3 hours at $37^{\circ} \mathrm{C}$. The liberated OT alpha was analyzed by HPLC under the same conditions mentioned under OTA.

3. Statistical analysis:

Data were analyzed using parametric statistical test (Student's ttest), by SPSS statistical program.

\section{Results}

The different groups studied as well as their demographic and biological data are shown in Tables $1 \& 2$.

Table 1. Different groups included in the present study

\begin{tabular}{|c|c|c|c|c|c|}
\hline \multirow{2}{*}{ Group } & \multirow{2}{*}{ Diagnosis } & \multicolumn{2}{|c|}{$\operatorname{Sex}$} & \multicolumn{2}{|c|}{ Age } \\
\hline & & Male & Female & Range & $M \pm S . D$. \\
\hline 1 & ESRD & 7 & 4 & $09-55$ & $34.6 \pm 13.1$ \\
\hline II & ESRD under dialytic treatment & 13 & 2 & $10-58$ & $35.2 \pm 10.5$ \\
\hline III & Kidney transplant recipients & 12 & 3 & $18-43$ & $31.1 \pm 8.8$ \\
\hline IV & Nephrotic syndrome & 8 & 7 & $05-50$ & $21.7 \pm 13.7$ \\
\hline v & Urothelial tumors & 13 & 2 & $38-70$ & $50.4 \pm 7.6$ \\
\hline VI & Kidney donors & 9 & 6 & $22-50$ & $33.0 \pm 9.0$ \\
\hline VII & Healthy controls & 18 & 7 & $21-49$ & $33.4 \pm 7.4$ \\
\hline
\end{tabular}

Ochratoxin A levels were determined in the five different groups with renal diseases as well as two control groups. A total of 231 samples of blood, urine and tissue biopsy specimens were obtained for OTA determination. The mean \pm S.D. are showed in (Table 3).

Tables 2. Biological data of the studied groups

\begin{tabular}{|c|c|c|c|c|c|c|}
\hline \multirow{2}{*}{ Group } & \multicolumn{6}{|c|}{ Biological data (Mean \pm S.D.) } \\
\hline & $\begin{array}{l}\text { Creatinine } \\
\mathrm{mg} \%\end{array}$ & $\begin{array}{l}\text { Uric acid } \\
\mathrm{mg} \%\end{array}$ & $\begin{array}{l}\text { Hemoglobin } \\
\text { gm\% }\end{array}$ & $\begin{array}{l}\text { Proteinuria } \\
\mathrm{gm} / 24 \mathrm{~h}\end{array}$ & $\begin{array}{l}\mathrm{Na} \text { in urine } \\
\mathrm{mmol} / \mathrm{l}\end{array}$ & $\begin{array}{l}\mathrm{K} \text { in urine } \\
\mathrm{mmol} / \mathrm{t}\end{array}$ \\
\hline$I(n=11)$ & $9.04 \pm 2.34$ & $9.2 \pm 1.75$ & $8.49 \pm 1.44$ & $2.15 \pm 1.18$ & $25.3 \pm 12.78$ & $55.26 \pm 25.05$ \\
\hline II $(n=15)$ & $14.43 \pm 4.04$ & $9.38 \pm 2.30$ & $6.74 \pm 1.18$ & $1.49 \pm 0.80$ & $80.51 \pm 32.78$ & $34.84 \pm 15.12$ \\
\hline III $(n=15)$ & $1.59 \pm 0.46$ & $6.07 \pm 1.84$ & $11.81 \pm 2.27$ & $0.3 \pm 0.84$ & $116.7 \pm 47.66$ & $39.51 \pm 10.13$ \\
\hline IV $(n=15)$ & $1.09 \pm 0.53$ & $5.82 \pm 1.32$ & $10.85 \pm 2.13$ & $2.09 \pm 1.05$ & $97.92 \pm 22.63$ & $26.53 \pm 9.95$ \\
\hline$V(n=15)$ & $1.31 \pm 0.87$ & - & $12.72 \pm 2.49$ & $0.43 \pm 0.68$ & - & - \\
\hline VI $(n=15)$ & $0.77 \pm 0.16$ & $4.99 \pm 0.96$ & $13.81 \pm 1.44$ & 0 & $164.1 \pm 54.11$ & $48.43 \pm 18.14$ \\
\hline VII $(n=25)$ & $0.90 \pm 0.14$ & $5.16 \pm 1.38$ & $13.71 \pm 1.39$ & 0 & $205.1 \pm 63.13$ & $59.59 \pm 25.55$ \\
\hline
\end{tabular}


Table 3. Concentration of OTA in blood, urine $(\mathrm{ng} / \mathrm{ml})$ and tissue $(\mathrm{ng} / \mathrm{g})$

\begin{tabular}{|c|c|c|c|c|c|c|c|c|c|}
\hline \multirow{2}{*}{ Group } & \multicolumn{3}{|c|}{ OTA (serum) } & \multicolumn{3}{|c|}{ OTA (urine) } & \multicolumn{3}{|c|}{ OTA (rissue) $n=14$} \\
\hline & Mean & S.D. & Range & Mean & S.D. & Range & Mean & S.D. & Range \\
\hline $1(n=11)$ & 1.01 & 1.56 & $0-3.75$ & 1.85 & 2.82 & $0-6.70$ & & & \\
\hline $11(n=15)$ & 0.34 & 0.69 & $0-2.17$ & 0.36 & 1.21 & $0-4.0$ & & & \\
\hline III $(n=15)$ & 0.47 & 1.62 & $0-6.30$ & 0.12 & 0.36 & $0-1.36$ & & & \\
\hline IV $(n=15)$ & 2.19 & 3.07 & $0-10.15$ & 3.09 & 3.47 & $0-8.19$ & & & \\
\hline$V(n=15)$ & 0.52 & 1.46 & $0-5.57$ & 0.36 & 1.20 & $0-4.64$ & 0.26 & 0.46 & $0-1.28$ \\
\hline VI $(n=15)$ & 0.08 & 0.24 & 0.0 .91 & 0.26 & 0.91 & $0-3.42$ & & & \\
\hline VII $(n=25)$ & 0 & 0 & $0-0$ & 0.01 & 0.0 & $0-0.31$ & & & \\
\hline
\end{tabular}

\section{Ochratoxin A levels in all group}

Group I: ESRD under conservative medical treatment $(\mathrm{N}=11)$

$2 / 11$ were + ve for OTA in blood $(0.99,3.69 \mathrm{ng} / \mathrm{ml})$. $2 / 11$ were + ve for OTA in urine $(6.66,6.70 \mathrm{ng} / \mathrm{ml})$. $2 / 11$ were + ve for OTA in blood $(2.63,3.75 \mathrm{ng} / \mathrm{ml})$. and in urine $(2.18,4.81 \mathrm{ng} / \mathrm{ml})$.

Group II: ESRD under dialytic therapy $(\mathrm{N}=15)$

$4 / 15$ were + ve for OTA in blood $(0.34-2.17 \mathrm{ng} / \mathrm{ml})$. $1 / 11$ was + ve for OTA in urine $(4.0 \mathrm{ng} / \mathrm{ml})$.

4 patients were totally anuric.

Group III: Renal transplant recipients $(N=15)$

$2 / 15$ were + ve for OTA in blood $(0.81,6.30 \mathrm{ng} / \mathrm{ml})$. $2 / 15$ were + vc for OTA in urine $(0.43,1.36 \mathrm{ng} / \mathrm{ml})$.

Group IV: Patients presenting with nephrotic syndrome $(\mathrm{N}=15)$

$1 / 15 \mathrm{was}+$ ve for OTA in blood $(0.32 \mathrm{ng} / \mathrm{ml})$.

$1 / 15 \mathrm{was}+$ ve for OTA in urine $(7.84 \mathrm{ng} / \mathrm{ml})$.

$7 / 15$ werc + ve for OTA in blood $(0.69-10.15 \mathrm{ng} / \mathrm{ml})$. and in urine $(0.67-8.19 \mathrm{ng} / \mathrm{ml})$.

Group V: Urothclial tumors $(\mathrm{N}=15)$

$3 / 15$ were + ve for OTA in blood $(0.80-5.57 \mathrm{ng} / \mathrm{ml})$.

$1 / 15 \mathrm{was}+$ ve for OTA in urine $(4.64 \mathrm{ng} / \mathrm{ml})$.

$3 / 14$ wcre + ve for OTA in lissue $(0.51-1.28 \mathrm{ng} / \mathrm{g})$.

Group VI: Control group A "potential kidncy donors" $(\mathrm{N}=15)$.

$1 / 15$ was + ve for OTA in blood $(0.91 \mathrm{ng} / \mathrm{ml})$.

$1 / 14$ was + ve for OTA in urine $(3.42 \mathrm{ng} / \mathrm{ml})$.

$1 / 15$ was + ve for OTA in blood $(0.30 \mathrm{ng} / \mathrm{ml})$ and for urine $(0.22 \mathrm{ng} / \mathrm{ml})$.

\section{Group VII: Control group B $(\mathrm{N}=25)$}

All members enrolled in this group were healthy people working at the Urology and Nephrology Center, Mansoura, Egypt. They were clinically, labo- ratory and radiologically free and having negative past or family history of renal troubles.

Urinary B2 microglobulin all control subjects were very low or abscent $(12.1 \pm 12.2$ with range of $0-46$ $\mathrm{ng} / \mathrm{ml}$ ) and this was a major criterion for inclusion in this group. The normal levels for $\mathrm{B} 2$, microglobulin in urine was $94.8 \pm 10.8 \mathrm{ng} / \mathrm{ml}(21)$, only one patient in this group had OTA in urine $(0.31 \mathrm{ng} / \mathrm{ml})$ and no one has OTA in blood.

Statistically highly significant ochratoxin A levels were found in all groups in comparison with the control groups $(p<0.001)$ (Table 4).

Table 4. Comparison of OTA levels in different studied groups.

\begin{tabular}{lll}
\hline & \multicolumn{2}{c}{$P$} \\
Compared groups & \multicolumn{2}{c}{ Urine } \\
\cline { 2 - 3 } & \multicolumn{1}{c}{ Serum } \\
\hline & & \\
(VI, VII) Vs I & 0.0001 & 0.0001 \\
(VI, VII) Vs II & 0.0001 & 0.036 \\
(VI, VII) Vs III & 0.001 & $0.889 *$ \\
(VI, VII) Vs IV & 0.0001 & 0.0001 \\
(VI, VII) Vs V & 0.0001 & 0.044 \\
(I) Vs II & 0.004 & 0.003 \\
(II) Vs IV & $0.011^{*}$ & $0.559 *$ \\
(II) Vs III & $0.390 *$ & $0.103 *$ \\
(I) Vs III & $0.334^{*}$ & 0.0001 \\
& & \\
\hline
\end{tabular}

No significant differences for $p>0.05 *$

Significantly higher ochratoxin A levels were found in group I compared to patients with ESRD on dialysis therapy, probably denoting clearance of OTA with dialysis $(\mathrm{p}<0.001)$.

OTA blood levels were significantly higher in patients with ESRD than their potential kidney donors $(p<0.01)$ although insignificant differences of their urinary OTA levels were noted (Table 4).

No statistical significant differences were found comparing OTA blood and urinary levels between 
patients with ESRD under dialysis and renal allograft recipients (i.e. post transplantation).
The pathological diagnoses and OTA levels (mean \pm S.D.) of groups 4 and 5 are shown in (Table 5).

Table 5. Pathological diagnoses and OTA levels (mean \pm S.D.) of groups IV and $V$

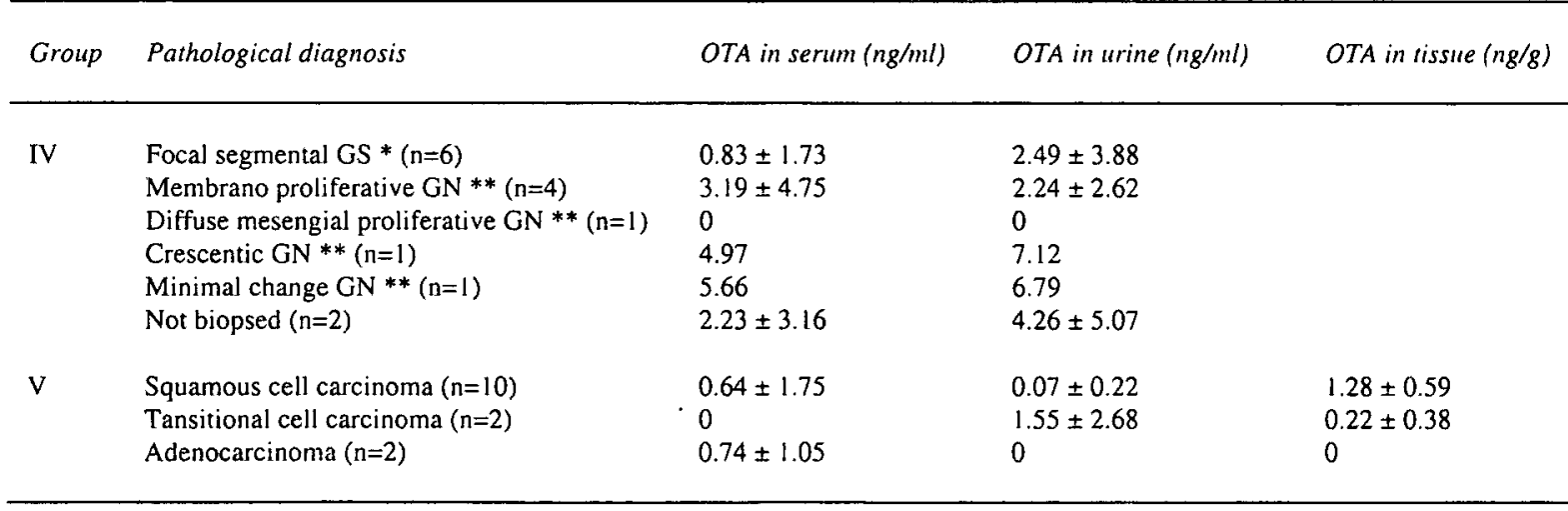

$\mathrm{GS}=$ Glomerulosclerosis *, GN = Glomerulonephritis **

\section{Discussion}

Mycotoxicosis are becoming increasingly implicated in human and animal diseases both in industrial and developing countries. Malnutrition, climatic factors (temperature, humidity, $\mathrm{O} 2$ versus $\mathrm{CO} 2$ ratio), social conditions, enviromental pollution and certain behaviours as methods of food preservation are aggravating factors for mycotoxigenic effects [1].

All are accumulating factors that enhance proliferation of toxigenic fungi [21].

Recently, mycotoxins are considered potentially nephrotoxic [23]. OTA continues to have an uncertain role in chronic renal disease [24,25]. Data are still lacking about direct role of OTA in the genesis of renal diseases and there is still a debate whether OTA alone can induce nephropathy in man or there are additive or synergistic effects from two or more mycotoxins [26].

In this study, five groups of patients with renal diseases under different modalities of therapy were studied. We tried to find a correlation of OTA concentration in blood, urine or tissues and the type of renal lesion and also the effect of renal replacement therapy on OTA concentration.

Statistically significant higher OTA levels were detected in the uremic groups (1\&2) than controls $(p<0.01)$. A finding may implicate OTA in the genesis of renal lesion mounting to ESRD. The capacity of OTA to induce human nephropathy was previously reported [3].

There are several cases with undetermined etiology for which OTA was incriminated as Balkan Endemic Nephropathy [25], Chronic Interstitial Nephritis in Tunisia [17] and the Karyomegalic Interstitial Nephritis with progressive chronic renal disease [27].
Another evidence for OTA-induced nephropathy was found experimentally in animals so far examined as pigs, rats, dogs, hamsters, chickens .... etc and OTA was found to produce degeneration of the proximal portion of renal tubules, hyaline deposits in the free space of Bowman's capsule, atrophy of the glomeruli and in advanced stage interstitial cortical fibrosis and glomerular sclerosis [6].

The significantly lower OTA level in our uremic group under dialytic therapy (group 2) than those under conservative medical treatment (group 1) $(p<0.001)$ may be related to OTA clearance by dialysis although OTA is known to be firmly protein bound [6] or this result may be related to difference in patients enrolled in the different groups studied.

The high blood \& urine OTA levels detected in patients with nephrotic syndrome (group 4) ( $<<0.001$ ) compared to control groups could account partially for the glomerular as well as the tubulointerstitial lesions detected in their renal biopsy specimens, as it was previously reported clinically [3] and experimentally $(28,29)$ that OTA can produce tubulointerstitial lesions with atrophy of the proximal tubules, interstitial cortical fibrosis and glomeruloscleroris due to heavy deposition of the toxin.

Renal transplantation as an ideal model of therapy for ESRD was also explored in a relatively small number of our patients. Serum OTA content was higher than the control group $(p<0.0001)$ and their urinary OTA levels were higher than the uremic group I. This could be explained by restoration of normal renal function and modification of thcir dietary habits. In the group of urothelial cancer, the higher blood and urine OTA levels (than the control groups) $(P<0.05)$ and the detectable levels of OTA in their tissue specimens probably incriminate OTA In the genesis of urothelial tumors. Although both experi- 
mental and clinical evidence for OTA induced urethelial cancer are accumulating, yet the implication of OTA as a sole etiological factor is not fully proven [21].

The higher OTA values in the group of potential related kidney donors (+ve family history of renal disease) than the healthy control group may denote the possibility of family exposure to toxigenic fungi. However, the geographic distribution of OTA +ve patients was not studied as epidemiological survey on larger number of population will be more conclusive. Our data support the incrimination of OTA in the pathogensis of renal diseases and urethelial tumors. However, large epidemiological studies are now warranted to find out a more or less definite correlation between OTA and the occurance of different renal diseases leading to ESRD as well as the oncogenic potentials of OTA among our population.

\section{References}

1. Maaroufi K, Achour A, Zakhama A, Ellouz F, El May M, Creppy EE and Bacha H: Human nephropathy related to ochratoxin A in Tunisia. J.Toxicol Toxin Reviews, 1996; 15 (3): 223-237.

2. Van Der Merwe KJ , Steyn PS, Fourie L, Scott DB and Theron JJ: Ochratoxin A, a toxic metabolite produced by aspergillus ochraceus. Nature 1965; 205: 11/2-1113.

3. Simon, P: Ochratoxin and kidney disease in the human. J. Toxicol- Toxin Reviews, 1996; 15 (3): 239-249.

4. Krogh P, Hald B, Plestina R and Ceovic S: Balkan (endemic) nephropathy and food born ochratoxin A: A Preliminary results of a survey of foodstuffs. Acta path Microbiol Scand Sec B, 1977; 85: 238-240.

5. Bauer $J$ and Gareis $M$ : Ochratoxin $A$ in the food chain. Animal Reseach \& devclopment 1991: 33: 80-97.

6. Krogh P: Ochratoxins in food. In "Mycoloxin in food" ediled by P. krogh. Newyork, Academic press, 1987; 97-121.

7. Petkova-Bocharova $T$, Chernozemsky IN and Castegnaro $M$ : Ochratoxin $A$ in human blood in relation to Balkan Endemic Nephropathy and urinary system tumours in Bulgaria. Food Addit Contam., 1988: 5 (3): 299-301.

8. Kuiper GoodmanT and Scout PM: Review. Risk assessment of the mycoloxin ochratoxin A. Biomed Environ Sci 2 (3) 1989 ; 179-248.

9. Breitholk A, Olsen M, Dahalback A and Hult K: Plasma Ochratoxin $A$ levels in three swedish populations surveyed using ion-pair IIPLC technique. Food Addit contam, 1991: $8(2): 183-192$.

10. Creppy EE et al: Human ochratoxicosis in France. In" Mycotoxins, Endemic Nephropathy and Renal Tumours edited by $M$ Castegnaro, R Plestina, G. Dirheimer, I. Chernozemsky and M. Bartsch. Lyon, IARC scientific publicalion, 1991: 115: 1-7.

11. Creppy EE et al: Ochratoxin A. Human ochratoxicosis and its pathologies. (Creppy EE, Castcgnaro M, Dirheimer G, eds) Colloque INSERM 1 John Libbey EurotexI LTD, 1993; 231: 147-158.

12. Maaroufi K, Achour A, Hammami M, El-May M, Betbeder AM, Ellouz F, Creppy EE and Bacha $H$ : Ochratoxin A in human blood in relation to nephropathy in Tunisia. Human exp. toxicol 1995; 14: 609-615.

13. Krogh P: Mycotoxic nephropathy. Adv. Vet Sci Comp Med 1976; 20: 147-170

14. Pavlovic M, Plestina $R$ and Krogh P: Ochratoxin A contamination of foodstuffs in an area with Balkan (Endemic) Nephropathy. Acta path Microbiol Scand sect B, 1979; 87: 243-246.

15. Speijers GJA and Van Egmond HP: Worldwide ochratoxin A levels in food and feeds. In EE Creppy, M. Castegnaro, G. Dirheimer (eds). Human ochratoxicosis and its pathologies, Paris, Editions Inserm, 1993: 231: 85-100.

16. El Matri A: I'insuffisance rénale dans les pays Arabes Colloque International "Ochratoxicoses et néphropathies, situation endemique" Monastir 1994; 25-26 Nov: 11 (Résumé).

17. Achour A and El May M: Les néphropathies chroniques dans le centre Tunisien. Colloque international "Ochratoxicoses et nephropathies, situation endemique", Monastir 1994; 25-26 Nov: 12 (Résumé).

18. Wing AJ: Causes of end stage renal failure. In Cameron $S$, Davison AM, Grundeld JP, Kerr D, Ritz E (eds). Oxford textbook of clinical Nephrology, Oxford Medical Publications, 1992; $2: 1227-1236$

19. Di Parlo N, Guarnieri A, Garosi G, Sacchi G, Mangiaroti $\mathrm{AM}$ and Di Paolo $\mathrm{M}$ : Inhaled mycotoxins lead to acute renal failure. Neph. Dial Transplant 1994; 9 [Suppl 4]: 116-120.

20. Krogh P: Role of ochratoxin in disease causation. f.d. Chem Toxic 1992; 30 (3): 213-224

21. Castegnaro $M$, Chenozemsky IN, Hietanen $E$ and Bartsch H: Are mycotoxins risk factors for endemic nephropathy and associated urothelial cancers? Arch- Geschwulstforsch, 1990; 60 (4): 295-303.

22. Evrin PE and Wibell L: The serum levels of urinary excretion of B2 microglobulin in apparently healthy subjects. Scand J Clin lab Invest, 1972; 29: 69-74.

23. Frank HK: Food contamination by ochratoxin $A$ in Germany. In $M$ Castegnaro, $R$ Plestina, G., Dirheimer, IN Chernozemzky, H. Bartsch (eds): Mycotoxins, Endemic Nephropathy and Urinary tract umor. Lyon, International Agency for Research on Cancer, 1991; 115:77-81.

24. Bacha PH: The modulation of mycotoxin exposure in domestic animals and man: Can we affect what we can't control? Markers for mycotoxin nephrotoxicity in domestic animals and man.in EE Creppy, M, Castegnaro G, Dirheimer (ed): Human Ochratoxicosis and its pathologies, Paris, Editions Inserm, 1993, 231: 43-49.

25. Hall PW: Balkan Endemic Nephropathy: more questions than answers. Nephron, 1992, 62: 1-5.

26. Delacruzl and Bact PH: The role of ochratoxin A metabolism and biochemistry in animal and human nephrotoxicity. $J$ Biopharm Sci, 1990; 1: 277-304.

27. Mihatsch MJ, Gudat F, Zollinger HU, Heierli $\mathrm{CH}$, Tholen $\mathrm{H}$ and Reutter FW: Systemic Karyomegaly associated with chronic interstitial nephritis. A new disease entity ? Clin Nephrol 1979; 12: 54-62.

28. Carlton WW and Krogh P: Ochratoxins, a review. In " Shimoda W", conference on mycotoxins in animal feeds and grains related to animal healths. National Technical Information, Service, Springfiled, 1979; 166-288.

29. Mortensen T, Moller O, Petersen K, Ravnskov U, Rostgaard $M$ and Aalund: Experimental porcine nephropathy. Change of renal function and structure induced by OTA-contaminated food. Acta pak Microbiol Scand. Sect A, 1974; [Suppl 246]. 


\section{FRENCH ABSTRACTS}

I. Aspects diagnostiques et thérapeutiques de la lithiâse rénale récidivante.

II. Suivi des donneurs de reins dans un Centre d'Afrique du Sud.

III. L'hyperechogénicté du parenchyme rénal chez un donneur rénal apparenté potential: Justifie-telle l'exclusion.

IV. Rôle du tumour necrosis factor alpha sérique et ses récepteurs solubles dans la prédiction du rejet aigu de l'allogreffe rénale.

V. L'influence des groupes sanguins ABO sur la sensibilisation des reçeveurs potentiels de greffes rénales.

VI. Prévalence de la tuberculose rénale parmi les patients se présentant avec une tuberculose pulmonaire active à llorin, Nigéria.

VII. Malformations urogénitales majeures chez les enfants Nigériens.

VIII. L'ochratoxicose et la néphropathie en Egypte: Une étude préliminaire. 


\section{Aspects diagnostiques et thérapeutiques de la lithiâse rénale récidivante}

\section{Résumé:}

Les pourcentages des calculs recurrents des reins sont à $7.5 \%$ chez les hommes caucasiens et a $3.0 \%$ chez les femmes. Malgré l'urbanization des populations noires Sud Africaines, le pourcentage des calculs reste bas $(1 \%)$ chez les hommes et femmes noires.

Nous avons étudié les profiles métaboliques de 400 personnes avec des calculs récurrents, (tous, des patients de la clinique métabolique pour calculs). La thérapie de chaque sous - groupe est donnée, et les resultats des études métaboliques en conjonction avec les traitements sont aussi donnés. En addition, les facteurs lithogéniques ont été étudiés chez des sujets non-malades blancs et noirs, et chez des patients noirs avec des calculs. Ceci, pour clarifier la basse incidence de ces calculs chez les noirs.

Les patients furent classifiés selon les facteurs de risques diététiques et métaboliques lithogéniques. Le pourcentage des patients avec des calculs dans chaque groupe était ainsi: 12\% avec de l'hypercalciurie rénale; $10 \%$ avec de l'hypercalciurie absorptive; $20 \%$ avec de l'hyperoxalaurie métabolique modérée; $50 \%$ avec de l'hypocitraturie. Indapamide, carbonate de calcium, et citrate de potasse est une bonne thérapie pour combattre l'hypercalciurie rénale, l'hyperoxalurie métabolique modérée et aussi l'hypocitraturie. Les sujets noires nonmalades avaient un 24 heures taux d'éxcrétion de sodium dans leurs urine beaucoup plus haut que les sujets blancs, mais leurs taux d'éxcrétion de calcium, citrate et cystine était beaucoup plus bas. Aprés 24 heures, les taux de ces substances dans l'urine des patients noirs avec les calculs étaient presque les mêmes que ceux des patients noirs avec les calculs. Nous supposons que l'incidence d'urolithiasis est plus élevée chez les populations noires urbanisées.

Nous concluons que les profiles métaboliques sont essentielles pour les risques de facteurs métaboliques chez les patients avec des calculs de calcium oxalate. Ceci aide à developper les traitements qui sont specificques et trés éfficaces pour la prévention de récurrence.

\section{Suivi des donneurs de reins dans un Centre d'Afrique du Sud}

\section{Résumé:}

Idée de base: Il y a une pćnurie mondiale de donneurs d'organes. Le probléme est même plus aigu dans notre province de KwaZulu / Natal où la proportion de dons d'organes de cadavres est très basse. Tant les patients que les néphrologues sont sous pression pour trouver des donneurs vivants.

Méthode et résultats: Nous avons étudié 135 donneurs vivants de reins sur un période de dix ans, 85 femmes et 50 hommcs; $78(57,8 \%)$ ćtaient d'origine Indiennc, $33(24,4 \%)$ noirs, $15(11,1 \%)$ blancs et $9(6,7 \%)$ de races mélangées. La majorité des donneurs faisaient parti de la fratrie (57\%), 14,8\% étaient des parents, $6,7 \%$ des enfants, $17,8 \%$ des ćpoux et $3,7 \%$ des cousins. L'âge moyen des donneurs était 34,2 ans (de 21 â 56 ans). Les donneurs ont ćlć hospitalisés pour période moyenne de 6,1 jours (de 3 à 15). Les complications postopératoires ont ćlé une atalectasie lobaire gauche et infection pulmonaire chez $11,1 \%$ et d'autres infections chez $5,2 \%$, un pncumothorax chez $2,2 \%$, un ileus paralytique dans deux cas, une dépression dans un cas et des doulcurs prolongces â l'endroil de l'općration chez $11,1 \%$. Une protéinurie a étć notée dans trois cas $(0,26$ $\mathrm{gm} / \mathrm{j}$ et $0,66 \mathrm{gm} / \mathrm{j}$ che $z$ dcux donneurs aprés 2 ans et $0,27 \mathrm{gm} / \mathrm{j}$ dans le trosième cas après $10 \mathrm{ans}$ ). La tension artćriclle n'a pratiquement pas changé.

Conclusion: Cette ćtude confirme que la nćphrectomie unilatérale chez les individus sains n'est associée qu'à peu d'effets secondaircs majeurs et que les donneurs vivants pour transplantations rénales constituent une alternative possible. 
L'hyperechogénicté du parenchyme rénal chez un donneur rénal apparenté potential: Justifie-t-elle

\section{l'exclusion}

\section{Résumé:}

Le but de cette étude est d'évaluer l'importance de l'échogénicité de degré I chez un donneur de rein potentiel en l'absence d'anomalie urinaire et avec une fonction rénale normale.

Trente quatre donneurs apparentés ayant cette anomalie ont été inclus, les âges allaient de 23-48 ans. Dix donneurs sains ont été utilisés comme contrôles.

Tous les cas ont été étudiés par mesure de VFG par scanning isotopique et estimation de la réserve rénale par infusion de dopamine at d'aminoacides.

Une biopsie rénale a été faite pour 17 cas du groupe échogénique et 8 des contrôles. Notre étude a montré que la réserve rénale était comparable dans les deux groupes.

Des altérations glomérulaires ont été trouvées chez $41 \%$ des donneurs apparament normaux et seulement dans un cas des contrôles.

Conclusion: L'échogénicité de degré I peut être un signe de maladie rénale non reconnue. Une biopsie est obligatoire quand un donneur apparenté est le seul possible.

Rôle du tumour necrosis factor alpha sérique et ses récepteurs solubles dans la prédiction du rejet aigu

\section{de l'allogreffe rénale}

\section{Résumé:}

Le Tumour necrosis factor alpha (TNF- $\alpha$ ) est connu pour être impliqué dans la pathogénèse du rejet aigu de l'allogreffe rénale. Cependant l'évaluation isolée des taux sériques de cette cytokine ne représente pas un index fiable des épisodes de rejet aigu. Le TNF- $\alpha$ stimule la libération de récepteurs solubles (TNF-SR55 et TNFSR75) catabolisés par le rein et ayant un effet inhibiteur sur celui-ci.

Vingt-neuf reçeveurs de greffes rénales ont été étudiés et comparés à dix contrôles sains. TNF- $\alpha$, TNF-SR55 et TNF-SR75 ont été mesurés avant et après transplantation rénale. Les taux pré-transplantation étaient 26,3 \pm $9,7 \mathrm{pg} / \mathrm{ml}, 28,2 \pm 8,3$ et $42,5 \pm 11,1 \mathrm{ng} / \mathrm{ml}$ respectivement. Les patients ont été répartis selon l'évolution postopératoire en trois groupes. Groupe I (greffe stable: no $=17$ ): le taux moyen de TNF- $\alpha$ était de 7,5 $\pm 4,6 \mathrm{pg} / \mathrm{ml}$, TNF-SR55 6,4 $\pm 4,7$ et TNF-SR75 $12,5 \pm 8 \mathrm{ng} / \mathrm{ml}(\mathrm{p} \mathrm{NS}$ ). Groupe II (rejet aigu de l'allogreffe: no $=8$ ): Les taux moyens étaient $37,2 \pm 16,2 \mathrm{pg} / \mathrm{ml}, 16,9 \pm 9,6 \& 30,9 \pm 13,4 \mathrm{ng} / \mathrm{ml}$ respectivement $(\mathrm{p}<0,05)$. Groupe III (Cyclosporine (CS) néphrotoxicité: no $=4$ ). Les taux moyens de TNF- $\alpha$ étaient $9,9 \pm 2,1 \mathrm{pg} / \mathrm{ml}$ avec une augmentation significative pour les valeurs de ses récepteurs $(9,4 \pm 1,0 \& 21,2 \pm 6,8 \mathrm{ng} / \mathrm{ml} ;$ vs $5,5 \pm 1,2 \& 5,4$ $\pm 4,8 \mathrm{ng} / \mathrm{ml}$ respectivement $\mathrm{p}<0,01$ ).

Pour améliorer la valeur prédictive de cette cytokine et de ses récepteurs, nous avons calculé le rapport entre TNF- $\alpha$ et ses deux récepteurs (SR55-SR75).

Pendant le rejet aigu les valeurs du rapport comparé au contrôles étaient $2,4 \pm 0,6$ vs $1,4 \pm 0,7 \& 1,3 \pm 0,5$ vs $0,7 \pm 0,4$ respectivement $(p<0,01)$.

Cependant, ces rapports n'ont pas été différents de ceux du groupe de contrôle au cours de la toxicitć à la CSA, $1,5 \pm 0,5$ vs $2,0 \pm 0,7 \& 0,5 \pm 0,3$ vs $0,9 \pm 0,2$ respectivement ( $p<0,05$ ).

Donc TNF- $\alpha$ et les taux de ses récepteurs solubles pouraient avoir une valeur diagnostique dans le rejet de l'allogreffe rénale.

En conclusion: 1- TNF- $\alpha$ et ses récepteurs sont fortement augmentés au cours de l'hémodialyse. 2 - II n'y a pas de différence significative entre les contrôles sains et les patients ayant une greffe stable. 3 - Il y a une augmentation très significative du TNF- $\alpha$ et de ses récepteurs au cours du rejet aigu et en période prć-rejet (R2) en comparaison avec les contrôles internes. 4 - Il y a un diminution non significative de TNF- $\alpha$ au cours de la néphrotoxicité à CSA avec une augmentation significative de TNF-SR55, TNF-SR75 en comparaison avec les contrôles internes. 5 - Les rapports TNF- $\alpha$ / SR55 \& SR75 montrent une augmentation significative au 
Méthode: Revue rétrospective des cas.

Patients: Tous les enfants avec malformations urogénitales se présentant au Département de Pédiâtrie se l'University College Hospital, Ibaban, Une institution importante de soins tertiaires dans le Sud Ouest du Nigéria, durant la période de juillet 1985 à Décembre 1995.

Résultats principaux: Un total de 125 cas de malformations urogénitales majeures ont été vus pendant la durée de l'étude. La malformation la plus fréquente était les valves uréthrales postérieures $(40,0 \%)$, l'hypospadias $(18,4 \%)$ les organes génitaux externes ambigüs $(12,8 \%)$ et la vessie ectopique $(11,2 \%)$.

Le diagnostic prénatal est rare et la plupart des patients se présentent tardivement. Le taux de mortalité à la première admission était de $14,4 \%$ (18/125) surtout des cas de valves uréthrales postćrieures.

Conclusions: Les valves uréthrales postérieures formaient la majorité des malformations urogćnitales vues dans les cas étudiés.

La mortalité élevée reflète probablement la gravité des lésions et la présentation tardive des patients (en rapport avec la rareté du diagnostic prénatal). Une meilleur conaissance de ces lésions parmi les médecins pratiquant dans les pays en voie de dévelopement et une plus grande utilisation de l'échographie au troisième trimestre de la grossesse peut améliorer le prognostic par une détection et un traitement plus précoce.

\section{L'ochratoxicose et la néphropathie en Egypte: Une étude préliminaire}

\section{Résumé:}

Cette étude préliminaire a été conçue pour évaluer l'ampleur du problème de l'ochratoxicose et son rapport a vec les maladies rénales allant jusqu'à l'insuffisance rénale terminale (IRT) ou les tumeurs urothéliaies cn Egypte. Cette étude comprend 71 patients ayant des maladies rénales à prćsentations diverses.

Ils ont été divisés en cinq groupes: (groupe 1, no.=11) patients en IRT sous traitement conservateur, (groupe 2. No.=15) IRT sous hémodialyse régulière, (groupe 3 . No.=15) reçeveurs d'allogreffes rénales, (groupe 4. No.=15) patients avec syndrôme néphrotique, (groupe 5 . No.=15) patients avec tumeurs urothćliales. De plus deux groupes de contrôles ont été inclus; des donneurs de reins potentiels apparentćs (groupe 6. No.=15) et des contrôles sains sans antécédents familiaux de maladies rénales (groupe 7. No.=25).

Tous les groupes ont été soumis a une évaluation cliniquc, tests de laboratoire, radiologiques et histopathologiques quant à l'état rénal ainsi qu'un dosage du taux d'ochratoxine A dans le sang l'urine at dans les biopsies de patients ayant une tumeur urothćliale.

Des taux sanguins élevés d'ochratoxine ont ćté trouvés chez tous les patients en IRT (groupe $1 \& 2)(p<0,01$ ). Des taux sanguins plus élevćs ont été trouvćs dans le groupe sous traitement conservaleur (groupe 1 ) en comparaison avec les contrôles, peut être a cause d'une ćlimination de l'ochratoxinc A par la dialysc. L'ochratoxine A a ćtc détectée dans le sang et l'urine des reçeveurs de greffes rénales (groupe 3$)(p<0,01)$ et des taux particulièrement élevés ont été trouvés chez les patients ayant un syndrome néphrotique (groupe 4) ( $p$ $<0,001)$.

Des taux d'ochratoxine élevés ont été trouvés dans le sang, l'urine el les biopsies du groupe avec tumcurs urothéliales (groupe 5$)(\mathrm{p}<0,01)$.

Ces résultats vont dans le sens de la conclusion que l'ochratoxin-A pourait ĉtre relic̀e à la genc̀se de maladics rénales conduisant à l'IRT ou à une tumeur urothéliale. Nous recommendons qu'une élude plus dćtaillée du problème de l'ochratoxine el des maladies rénales soit menće en Egyptc. 
cours du rejet aigu et une diminution non significative au cours de la néphrotoxicité à CS en comparaison avec les contrôles internes.

\section{L'influence des groupes sanguins $\mathrm{ABO}$ sur la sensibilisation des reçeveurs potentiels de greffes rénales}

\section{Résumé:}

Dans cette étude, 50 patients en insuffisance rénale chronique ont été testés quant au groupe sanguin $\mathrm{ABO}$ et pour la présence d'anticorps lymphocytotoxiques contre une palette de lymphocytes de 20 donneurs (de type HLA connus) en utilisant un test de microcytotoxicité. L'influence des autres facteurs agissant sur la sensibilisation, comme le nombre de transfusions sanguines, les grossesses et les rejets de greffes antérieures, a également été analysé. Les résultats montrent que $41,2 \%$ des patients du groupe $\mathrm{O}, 61,1 \%$ du groupe $\mathrm{A} 1,90 \%$ du groupe $B$ et $80 \%$ du groupe AIB étaient sensibilisés (PRA $>10 \%$ ).

Ces résultats montrent que les groupes $B$ et $A B$ ont une proportion plus forte de sensibilisation comparés aux groupes $A l$ et $O$ suggèrant un impact que le systeme $A B O$ semble avoir sur le phénomène de sensibilisation.

Prévalence de la tuberculose rénale parmi les patients se présentant avec une tuberculose pulmonaire active à Ilorin, Nigéria.

\section{Résumé:}

La tuberculose (TB) est un problème de santé mondial majeur, spécialement dans les pays en voie de dévelopement, elle affecte les différents organes du corps. Le rein est généralement affecté au cours de la dissćmination hématogène d'un foyer primaire. La TB rénale est la forme la plus commune de TB extrapulmonaire particulièrement chez les caucasiens mais est supposée être rare chez les noirs, ceci à cause du peu de données concernant la prévalence de la TB rénale. Une étude prospective a été entreprise pour étudier la prévalence de la TB rénale dans les cas de TB pulmonaire (TBP) active à Ilorin, Nigéria.

Les cas confirmés de TBP active ont étć subséquament recrutés de la clinique de pneumologie et de la salle de TBP active sur une période d'un an. Les critères d'inclusion étaient une positivité de crachats pour le BK deux fois ou plus et une preuve radiologique de TBP active. Les patients remplissant les conditions ci-dessus ont eu un examen des urines pour pyurie stérile, une coloration $\mathrm{Z}-\mathrm{N}$, une radiographie abdominale sans contraste, une échographie rénale un urogramme intraveineux et une biopsie rénale.

Un total de 148 cas de TBP active a été étudié (91 hommes, 57 femmes). Le rapport hommes/femmes était 3:2.

La moyenne d'age des hommes et femmes avec TB rónale était de 40 et 29 ans respectivement.

La prévalence du BK dans l'urine et la pyurie stérile étaient de $9,5 \%$ et $8,8 \%$ respectivement. Seul $2,7 \%$ avaient à la fois le KB dans l'urine et une pyurie stérile.

L'histologie rónale était anormale dans $70 \%$ des biopsies rénales avec pyurie stérile. La combinaison du BK dans l'urine et la preuve histologique de TB rénale a augmenté la prévalence de TB rénale à $14 \%$ dans cette étude.

Cette ćtude montre que la TB rénale dans les cas de TBP pourait étre comparable dans les populations blanches et noires.

Le diagnostic est difficile et il faut allier des outils diagnostiques à un haut degré de suspicion clinique.

\section{Malformations urogénitales majeures chez les enfants Nigériens}

\section{Résumé:}

Idée de base: $I l$ y a peu de donnćes sur les types de malformations urogénitales dans bien des pays aux resources pauvres, comme le Nigćria.

Objectif: Dćcrire les types de malformations urogénitales chez les enfants se présentant dans un Centre de soin tertiaire dans la région subsaharienne Africaine. 